\title{
First report of Euschistus heros (Hemiptera: Pentatomidae) damaging teak trees (Tectona grandis) in the neotropics
}

\author{
Primer registro del ataque de Euschistus heros (Hemiptera: Pentatomidae) en árboles de \\ teca (Tectona grandis) en el neotrópico
}

\section{JERFFERSONEY GARCIA COSTA ${ }^{1}$; LEONARDO LEITE FIALHO-JUNIOR ${ }^{2}$; ISABEL CAROLINA DE LIMA SANTOS ${ }^{3}$; RONALD ZANETTI"; ALEXANDRE DOS SANTOS 5}

\begin{abstract}
${ }^{1}$ Forest Engineering student, Phytosanitary Laboratory (FitLab), Federal Institute of Mato Grosso (IFMT), Cáceres, Mato Grosso, Brazil, jeffersoney.garcia@ gmail.com, https://orcid.org/0000-0003-4087-6464. ${ }^{2}$ Forest Engineer, Master student, Department of Entomology / BIOAGRO, Federal University of Viçosa, Viçosa, Minas Gerais, Brazil, leonardolfialho@gmail.com, https://orcid.org/0000-0001-7460-5406. ${ }^{3}$ Forest Engineer, Ph. D., Volunteer researcher, Phytosanitary Laboratory (FitLab), Federal Institute of Mato Grosso (IFMT), Cáceres, Mato Grosso, Brazil, isabelcarolinadelima@gmail.com, https://orcid.org/00000001-6810-6272. ${ }^{4}$ Forest Engineer, Ph. D., Professor, Department of Entomology, Federal University of Lavras, Lavras, Minas Gerais, Brazil, zanetti@ufla. $b r$, https://orcid.org/0000-0001-5698-1838. ${ }^{5}$ Forest Engineer, Ph. D., Professor, Phytosanitary Laboratory (FitLab), Federal Institute of Mato Grosso (IFMT), Cáceres, Mato Grosso, Brazil, alexandre.santos@cas.ifmt.edu.br, https://orcid.org/0000-0001-8232-6722.
\end{abstract}

\section{Corresponding author}

Alexandre dos Santos. Forest Engineer, Ph. D., Professor, Phytosanitary Laboratory (FitLab), Federal Institute of Mato Grosso (IFMT), Cáceres, Mato Grosso, Brazil, alexandre.santos@ cas.ifmt.edu.br, https://orcid.org/0000-00018232-6722

\section{Suggested citation}

COSTA, J. G.; FIALHO-JUNIOR, L. L.; SANTOS, I. C. L.; ZANETTI, R.; SANTOS, A. 2020. First report of Euschistus heros (Hemiptera: Pentatomidae) damaging teak trees (Tectona grandis) in the neotropics. Revista Colombiana de Entomología 2020, 46 (2): e8489. https://doi. org/10.25100/socolen.v46i2.8489

Received: 5-Sep-2019

Accepted: 18-Feb-2020

Published: 30-Dec-2020

Revista Colombiana de Entomología ISSN (Print): 0120-0488

ISSN (On Line): 2665-4385

https://revistacolombianaentomologia.univalle.edu.co

Open access

(c) (i) (ㅇ) BY-NC-SA 4.0

Publishers: Sociedad Colombiana de Entomología SOCOLEN (Bogotá, D. C., Colombia) https://www.socolen.org.co

Universidad del Valle (Cali, Colombia)

https://www.univalle.edu.co

(C) 2020 Sociedad Colombiana de Entomología SOCOLEN y Universidad del Valle - Univalle
Abstract: Teak, Tectona grandis is one of the most valuable woods in the world. In Brazil, it is attacked by sap-sucking insects such as Euschistus heros, known as Neotropical brown stink bug. Here we report the first occurrence of this pest in teak tree plantations in Cáceres, Mato Grosso, Brazil. The injuries on the trees were characterized and photographed, along with the insects collected on plants. Injuries caused the apical bud to dry, advancing to the entire plant drying. Injuries occur from the histological damage caused by insect stylets and the toxic enzyme released into plant cells.

Keywords: Forest entomology, insect damage, neotropical brown stink bug, teak, Euschistus heros, Hemiptera, Pentatomidae.

Resumen: La teca, Tectona grandis es una de las maderas más valiosas del mundo. En Brasil es atacado por insectos plaga chupadores de savia. Entre ellos se encuentra Euschistus heros conocido como chinche de la soya. Este trabajo tuvo como objetivo registrar, por primera vez, la aparición de esta plaga en plantaciones de árboles de teca en Cáceres, Mato Grosso, Brasil. Las lesiones causadas por $E$. heros en los árboles se caracterizaron y fotografiaron. Los insectos se recolectaron en las plantas. Las lesiones causaron el secado del brote apical, avanzando al secado total de la planta. Estas lesiones se producen por el daño histológico causado por el estilete de insecto y la enzima tóxica liberada en las células vegetales.

Palabras clave: Entomología forestal, daño de insectos, chinche de la soya, teca, Euschistus heros, Hemiptera, Pentatomidae.

\section{Introduction}

Sustainable production of timber and non-timber products from planted forests of exotic origin, such as Eucalyptus spp. (Myrtaceae) and Pinus spp. (Pinaceae) are sources of wealth and employment. Tectona grandis L. (Lamiaceae), known as teak, is also one of the most important species and concentrates a considerable part of its plantations in Mato Grosso state, Brazil. It was introduced commercially in the country in the municipality of Cáceres, in the decade of 1960 (Rosa et al. 2017).

Tectona grandis is a species from tropical forests of Southeast Asia, specifically India, Myanmar, Thailand and Laos, areas with remarkable climatic variations. This demonstrates the high adaptability of this species to diverse environments, being a great investment opportunity in Brazil due to its adaptation to the edaphoclimatic conditions in several regions (Paes et al. 2014).

Homogeneous teak plantations can be infested by various types of pests of economic importance, such as the sap-sucking insects Nezara viridula Linnaeus, 1758, Edessa meditabunda (Fabricius, 1794), Piezodorus guildinii (Westwood, 1837) and 
Maconellicoccus hirsutus (Green, 1908), which cause relevant economic losses (Nascimento et al. 2016).

This note aims to report the first occurrence of the Neotropical brown stink bug, Euschistus heros (F.), damaging commercial plantations of Tectona grandis located in Cáceres, Mato Grosso state, Brazil.

\section{Materials and methods}

The insect infestation was detected in December 2018, in the municipality of Cáceres $\left(57^{\circ} 40^{\prime} 51^{\prime \prime} \mathrm{W} 16^{\circ} 11^{\prime} 42^{\prime \prime} \mathrm{S}\right.$ and altitude of $117 \mathrm{~m}$ ), Mato Grosso state, Brazil. The injuries in leaves and apical buds on the T. grandis trees were inspected and photographed, and bug specimens feeding on damaged tissues were collected in 63 random plants samples using an entomological net. Adult insects were collected and preserved in $70 \%$ alcohol for identification. Voucher specimens were deposited in the Forest Protection Collection of the Phytosanitary Laboratory of the Federal Institute of Mato Grosso - Campus in Cáceres.

\section{Results and discussion}

The specimens were identified as Euschistus heros. The insects were detected in a $10-94$ months-year-old clonal teak commercial stand, planted at $4 \times 4 \mathrm{~m}$ spacing in 10 ha (Fig. 1). In this stand, the insects suck the plants and promote the drying of the apical or terminal bud (Fig. 2A), which soon evolved to a total drought of the plants (Fig. 2B). Stink bugs (Pentatomidae) inject enzymes present in their saliva. These enzymes fuse and dissolve the protein body of plant cells (Depieri and Panizzi 2011), which may explain the drying of teak plants. The morphology of their stylet and the biochemical characteristics of the enzyme present in their saliva causes histological damage and physiological and biochemical disorders to the cells in grains (Depieri and Panizzi 2011).

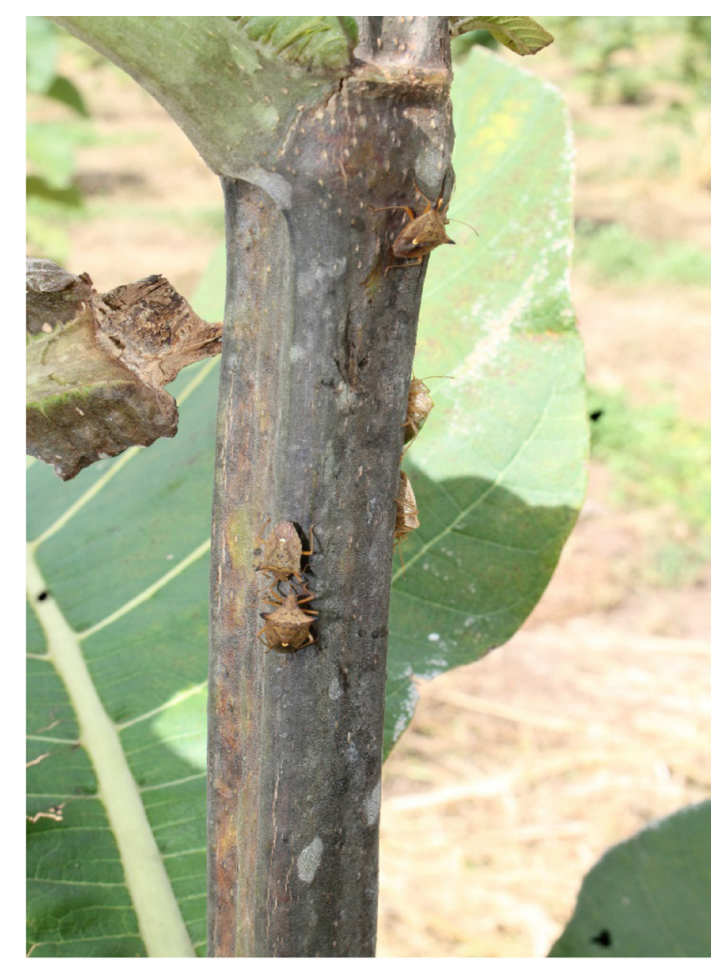

Figure 1. Euschistus heros adults on teak plants.
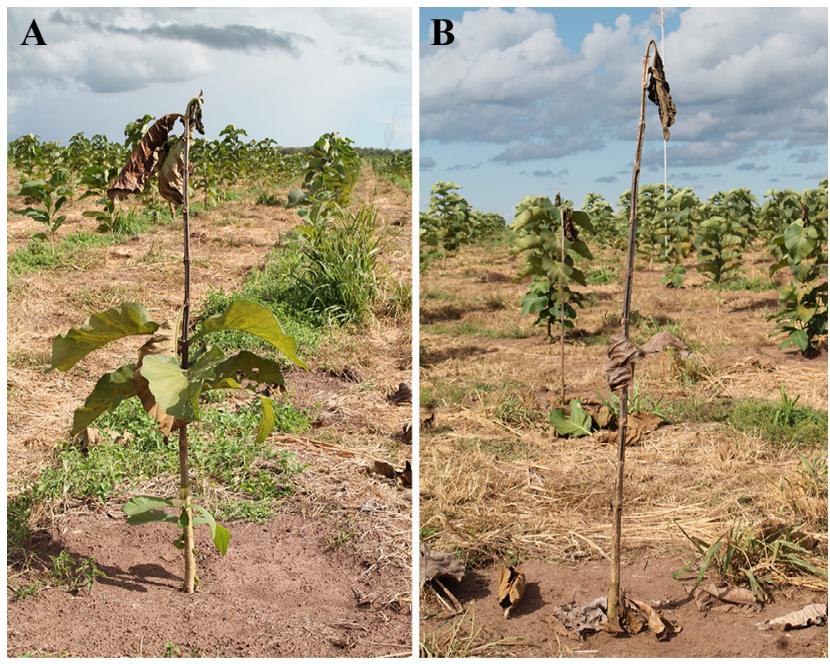

Figure 2. A. Chlorotic (yellowish green color) leaves of Tectona grandis trees due to damage by Euschistus heros. B. Dry T. grandis plant as a result of the feeding activity of $E$. heros.

Euschistus heros is a polyphagous species that feed on a variety of crops of economic importance. It is one of the main economic pests for soybean cultivation in Brazil and may reach a density of 40 - 60 individuals per $\mathrm{m}^{-1}$ during the harvest (Soza-Gómez and Silva 2010; Roza-Gomes et al. 2011; Paes et al. 2014; Husch et al. 2018). After harvesting, the bug feeds on alternate hosts (Ribeiro et al. 2016), which may explain its dispersion to the teak plants.

\section{Acknowledgements}

To "Pró-reitoria de Pesquisa, Pós-Graduação e Inovação (PROPES) do Instituto Federal de Educação, Ciência e Tecnologia de Mato Grosso (IFMT)" for research funding support. To Prof. Jocelia Grazia from the Department of Zoology, Federal University of Rio Grande do Sul, for the identification of the specimens.

\section{Literature cited}

DEPIERI, R. A.; PANIZZI, A. R. 2011. Duration of feeding and damage to soybean seed by stink bugs. Neotropical Entomology 40 (2): 197-203. https://doi.org/10.1590/S1519566X2011000200007

HUSCH, P. E.; FERREIRA, D. G.; SERAPHIM, N.; HARVEY, N.; SILVA-BRANDÃO, K. L.; SOFIA, S. H.; SOSA-GÓMEZ, D. R. 2018. Structure and genetic variation among populations of Euschistus heros from different geographic regions in Brazil. Entomologia Experimentalis et Applicata 166 (3): 191-203. https://doi.org/10.1111/eea.12666

NASCIMENTO, D. A.; ANUNCIAÇÃO-Jr, R. M.; ARNHOLD, A.; FERRAZ-FILHO, A. C.; SANTOS, A.; ZANUNCIO, J. C. 2016. Expert system for identification of economically important insect pests in commercial teak plantations. Computers and Electronics in Agriculture 121: 368-373. https://doi.org/10.1016/j. compag.2015.12.024

PAES, J. B.; LOIOLA, P. L.; CAPELINI, W. A.; SANTOS, L. L.; SANTOS JUNIOR, H. J. G. 2014. Entomofauna associada a povoamentos de teca localizados no sul do Estado do Espírito Santo. Pesquisa Florestal Brasileira 34 (78): 125-132. https://doi. org/10.4336/2014.pfb.34.78.675

RIBEIRO, F. C.; ROCHA, F. S.; ERASMO, E. A. L. MATOS, E. P.; COSTA, S. J. 2016. Manejo com inseticidas visando o controle 
de percevejo marrom na soja intacta. Revista de Agricultura Neotropical 3 (2): 48-53. https://doi.org/10.32404/rean.v3i2.1132

ROSA, T. F. D.; SCARAMUZZA, W. L. M. P.; FEITOSA, I. P.; ABREU, F. F. M. 2017. Produção e decomposição de serapilheira em povoamentos de teca no estado de Mato Grosso, Brasil. Ciência Florestal 27 (4): 1117-1127. https://doi. org $/ 10.5902 / 1980509830288$

ROZA-GOMES, M. F.; SALVADORI, J. R.; PEREIRA, P. R. V. S.; PANIZZI, A. R. 2011. Injuries of four species of stink bugs to corn seedlings. Ciência Rural 41 (7): 1115-1119. https://doi. org/10.1590/S0103-84782011005000081

SOZA-GÓMEZ, D. R.; SILVA, J. J. 2010. Neotropical brown stink bug (Euschistus heros) resistance to methamidophos in Paraná, Brazil. Pesquisa Agropecuária Brasileira 45 (7): 767-769. https://doi.org/10.1590/S0100-204X2010000700019

\section{Origin and funding}

The funding support of Pró-reitoria de Pesquisa, Pós-Graduação e Inovação (PROPES) do Instituto Federal de Educação, Ciência e Tecnologia de Mato Grosso (IFMT).

\section{Author contribution}

Jerffersoney Garcia Costa, Leonardo Leite Fialho-Junior and Alexandre dos Santos worked in the field, Jerffersoney Garcia Costa, Leonardo Leite Fialho-Junior, Isabel Carolina de Lima Santos, Ronald Zanetti and Alexandre dos Santos, wrote and edited the manuscript. All authors read and approved the final version of the manuscript. 